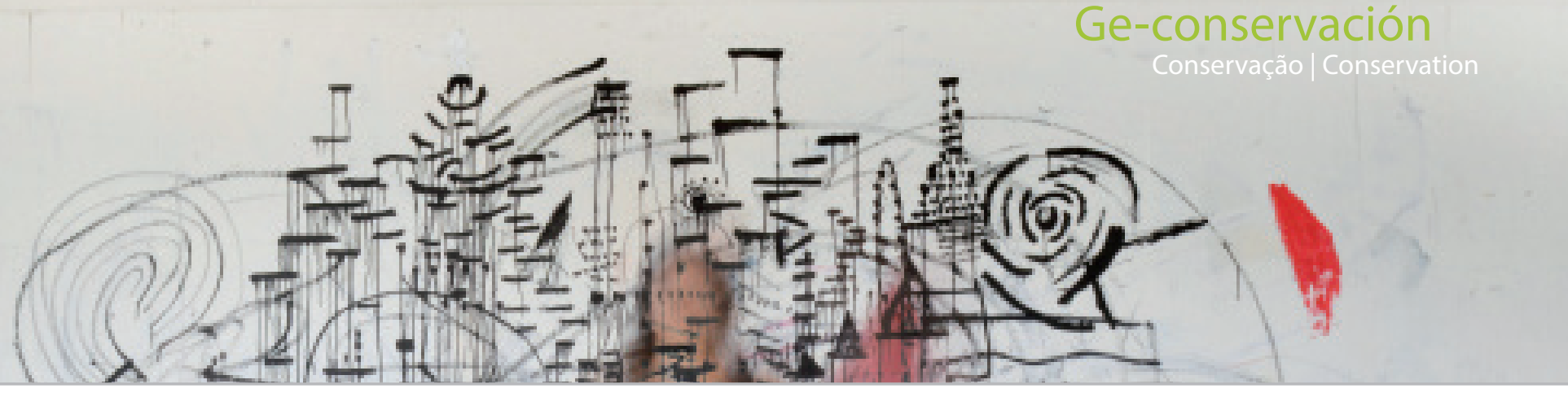

\title{
La autenticidad en el arte contemporáneo... ¿qué conservar?
}

\author{
Carlota Santabárbara
}

Resumen: La restauración del arte contemporáneo ha generado un gran debate teórico en torno a los criterios a seguir en los procesos de conservación-restauración y la reflexión teórica sobre qué conservar. En el panorama teórico actual surgen líneas de pensamiento que van más allá de la restauración crítica de Cesare Brandi, afrontando nuevos conceptos del arte como su significado, su inmaterialidad o su temporalidad, así como los procesos de copia, réplica y sustitución diferida que surgen desde la praxis en los foros internacionales, donde se ha tratado de buscar un modelo común de toma de decisiones que lleve a un trabajo riguroso y respetuoso con el arte contemporáneo.

Palabras clave: Arte Contemporáneo, autenticidad, materia, restauración, originalidad, copia, sustitución

\section{Authenticity in contemporary art: what do we conserve?}

Abstract: The conservation of contemporary art has generated a tremendous theoretical debate on the criteria followed in conservationrestoration processes and theoretical reflection on what to conserve. In the current theoretical panorama, lines of thought arise that go beyond Cesare Brandi's Theory of Restoration. New concepts of art such as its meaning, immateriality or impermanence, and the processes of copying, replication, and deferred substitution. These ideas arise from praxis in international forums, where they have tried to find a decision-making model that leads to rigorous and respectful procedures with contemporary art.

Keywords: Contemporary art, authenticity, material, conservation, originality, copy, replacement

\section{Introducción}

La dificultad que existe a la hora de enfrentarnos a la restauración de una obra de arte contemporánea tiene una doble complejidad, por un lado, los aspectos técnicos, que conciernen a la estabilidad de materiales nuevos y experimentales, y por otro lado, un conflicto teórico, de carácter reflexivo-crítico, ya que en muchas ocasiones, la cuestión radica en entender dónde reside la autenticidad de la obra para así, poder conservarla.

Cuando nos referimos al arte contemporáneo, consideramos un amplio abanico de disciplinas artísticas, que van desde la pintura o la escultura más tradicionales, al arte conceptual, la performance, el videoarte, la videoinstalación o el arte sonoro, entre otras; manifestaciones todas ellas de carácter artístico cuya razón de ser va desde el desarrollo de las mismas en el tiempo, su experimentación o el mismo proceso de percepción. De hecho, la complejidad que entraña el arte contemporáneo genera cierto desconcierto, dado que contiene valores que trascienden lo puramente material o

\section{Introduction}

The difficulty that exists when facing the conservation of a contemporary artwork is twofold. There are the technical aspects, which concern the stability of new and experimental materials, but also, the theoretical conflict. This possesses a reflexive-critical nature, since on many occasions, the question lies in understanding where the authenticity of the work is in regards to its conservation.

When we refer to contemporary art, we consider a wide range of artistic disciplines. From the more traditional painting or sculpture to conceptual art, performance, video art, video installation or sound art, all of the artistic manifestations whose raison d'être goes from their development over time, their experimentation or the very process of perception. In fact, the complexity of contemporary art generates an inevitable confusion, given that it contains values that transcend purely material or technical. All this 
técnico. Todo ello es consecuencia de la evolución que el arte ha experimentado en cuanto a su propia definición, afectando directamente a los criterios y principios que deben regirla.

Sirva como paradigma de estas afirmaciones la obra de Giovani Anselmo, (Scultura che mangia, 1968), que consiste en una lechuga que está sujeta a un pedestal de piedra mediante presión [Figura 1]. La obra se mantiene viva con la sustitución de parte de la obra (la lechuga) y su conservación-restauración consiste en que la obra permanezca activa (es decir, sustituir la lechuga cada dos días, antes de que pierda su frescura y rigidez).

Por ello, podemos vislumbrar que actualmente son muchos los factores a considerar en la toma de decisiones a la hora de intervenir en una obra de arte contemporáneo, desde la materialidad de la misma pieza, hasta los condicionantes externos, como el mercado, la pertenencia o no a una colección privada o pública, o incluso si todavía pertenece al artista. En este sentido, numerosos autores han afirmado la necesidad de nuevos criterios para el arte actual, apoyándose en la existencia de problemáticas particulares, contando con que el artista, en muchos casos sigue vivo y posee la propiedad intelectual de su obra, o en su defecto, son sus is a consequence of art's evolution in its definition, directly affecting the criteria and principles that should govern it.

The artwork of Giovani Anselmo Scultura che mangia (1968), which consists of a lettuce attached to a stone pedestal employing pressure [Figure 1], serves as a paradigm of these statements. The artwork is kept alive by replacing part of the work (the lettuce). Its conservation consists of allowing the work to remain active (i.e. replacing the lettuce every two days before it loses its freshness).

In cases like this, we can see that there are many factors to consider when making decisions about intervening in a contemporary artwork: from the materiality of the piece itself to external conditioning factors, such as the market, whether or not it belongs to a private or public collection, or even whether it still belongs to the artist. In this sense, numerous authors have affirmed the need for new criteria for contemporary art based on particular problems - considering that the artist, in many cases, is still alive and owns the intellectual property of their work, or, failing that, it is the heirs

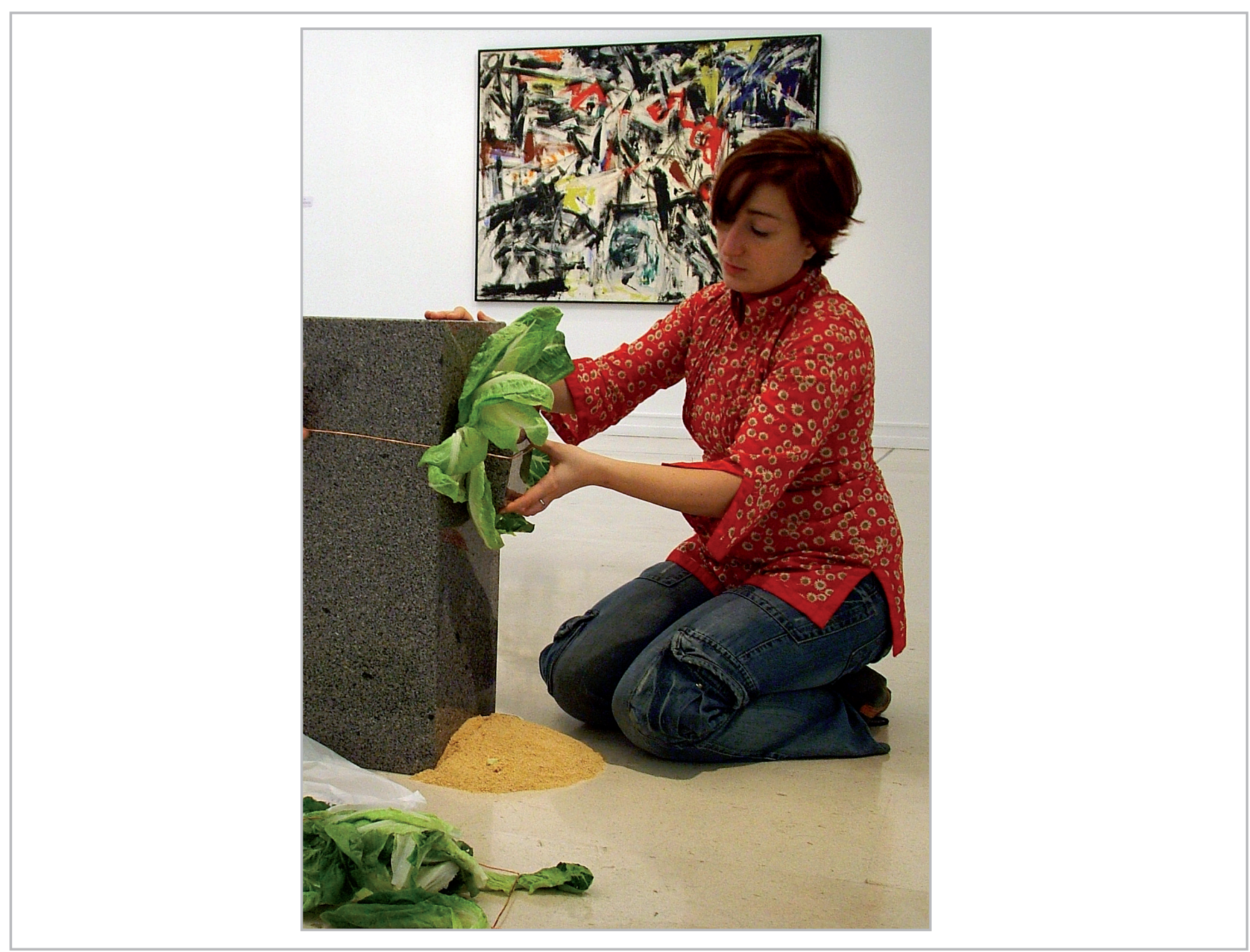

Figura/Figure 1.- Obra de Giovanni Anselmo. Sin título. (Scultura che mangia, 1968) Foto de la autora en las salas de exposiciones del IVAM, Valencia, 2006. / Work by Giovanni Anselmo. Untitled. (Scultura che mangia, 1968) Photo by the author in the exhibition rooms of IVAM, Valencia, 2006. 
herederos quienes la mantienen ${ }^{[1]}$. Por ello y como veremos a continuación, son muy importantes los proyectos e investigaciones en torno a la toma de decisiones, y cómo llegar a una óptima decisión de criterios de restauración, como es el caso de los estudios realizados entorno a las entrevistas a los artistas para documentar su intencionalidad, y así conocer la razón de ser del mismo, (Del Fresno-Guillem 2017).

La teoría de la conservación se debe adaptar a los nuevos tiempos, y por lo tanto surge la necesidad de reflexionar sobre este cambio de paradigma y cómo afecta directamente a la profesión y sobre todo averiguar dónde reside la autenticidad de la obra para mantenerla viva y transmitirla al futuro sin pervertir su esencia.

\section{Estado de la cuestión}

Si nos detenemos en analizar brevemente el estado de la cuestión, podemos vislumbrar el extenso análisis que se ha realizado sobre la materia en los últimos años, (Santabárbara 2016).

La reflexión teórica, se inicia ya en el siglo XIX, un momento convulso a nivel político y social que llevó a la preocupación y a cuestionarse sobre la conservación y la autenticidad de la forma y el material constitutivo de los monumentos a la hora de restaurarlos. Apareció una conciencia de responsabilidad de la conservación del original, siendo la reconstrucción-restauración el centro de un gran debate. De este modo se evidencia una evolución en el concepto de autenticidad a lo largo del tiempo, y cómo en el siglo XIX, primero se identificó con el aspecto formal (valga citar la restauración en estilo del arquitecto Eugène Emmanuel Viollet-le-Duc y el crítico John Ruskin quien presentaba una perspectiva totalmente opuesta al anterior). Por otro lado, el aspecto material, como depositario de la autenticidad de la obra, fue desarrollado por postulados más arqueológicos como las de Stern y Valadier, donde el valor residía en los restos materiales históricos, es decir, "auténticos".

De tal modo el material se convirtió en un testimonio histórico que conducía a la investigación en el campo del patrimonio cultural. Este postulado fue codificado en la Carta de Atenas (1930) y después en la Carta de Venecia (1964); en relación a la reposición de las lagunas y la sustitución de material histórico se declaró que las reconstrucciones eran totalmente inadmisibles. Huelga citar la conocida restauración crítica de Cesare Brandi, (Brandi 1963), donde se realizaba un análisis valorativo de la primacía de la imagen sobre la materia, planteando una metodología de restauración definida y bien conocida.

Cuarenta años después de la Carta de Venecia y debido a la necesidad de redefinir el alcance del concepto de autenticidad, surgió el Documento de Nara (1994). Dicho documento enfatizó la cuestión de la preservación de la autenticidad hoy en día en relación a la variedad cultural ${ }^{[2]}$. who maintain $\mathrm{it}^{[1]}$. For this reason, and as we will see below, projects and research on decision-making and how to reach an optimal decision on conservation criteria are critical. It is the case of the studies carried out around interviews with artists to document their intentionality, and thus understand their raison d'être (Del Fresno-Guillem 2017).

Conservation theory must adapt to the new times. Therefore, the need arises to reflect on this paradigm shift and how it directly affects the profession and, above all, to find out where the work's authenticity lies to keep it alive and transmit it to the future without perverting its essence.

\section{The state of the question}

If we stop to analyse the state of the question briefly, we can glimpse the extensive research that has been carried out on the subject in recent years (Santabárbara 2016).

The theoretical reflection began in the nineteenth century, a time of political and social upheaval that led to concern and questioning about the conservation and authenticity of the form and the constituent material of monuments when it came to restoring them. Awareness of responsibility for the conservation of the original appeared, with reconstruction-restoration being at the centre of a great debate. The concept of authenticity has thus evolved. In the 19th century, it was first identified with the formal aspect, citing the restoration in the style of the architect Eugène Emmanuel Viollet-le-Duc and the critic John Ruskin, who presented an opposite perspective to the previous one. On the other hand, the material aspect, as the repository of the work's authenticity, was developed by more archaeological postulates such as those of Stern and Valadier, where the value resided in the historical, i.e. "authentic," material remains.

The material thus became a historical testimony conducive to research in the field of cultural heritage. This postulate was codified in the Athens Charter (1930) and later in the Venice Charter (1964), concerning the replacement of lacunae and the substitution of historical material, reconstructions were inadmissible. Needless to say, the well-known The Theory of Restoration by Cesare Brandi (1963), where an evaluative analysis of the importance of the image over the material was carried out, proposing a defined and well-known conservationrestoration methodology.

Forty years after the Venice Charter and due to the need to redefine the scope of the concept of authenticity, the Nara Document (1994) emerged. This document emphasised the issue of preserving authenticity today concerning cultural variety ${ }^{[2]}$. In 
De hecho, ya en el Documento de Nara se menciona cómo han de tenerse en cuenta otros factores, que van más allá de lo material y lo histórico y que hay que atender a otros valores: "dependiendo de la naturaleza del patrimonio cultural, su contexto cultural, y su evolución a través de tiempo, los juicios de autenticidad pueden relacionarse a la validez de una gran variedad de fuentes de información. Los aspectos de las fuentes pueden incluir forma y diseño, materiales y substancia, uso y función, tradiciones y técnicas, la localización y contexto, espíritu y sentimientos, y otros factores interiores y exteriores". (ICOMOS 1994).

Por otro lado, el panorama profesional en el ámbito de la restauración del arte contemporáneo tomó un gran impulso a partir de 1993, cuando los museos de los Países Bajos especializados en arte contemporáneo decidieron unir sus fuerzas para realizar una investigación sobre las cuestiones relacionadas con la problemática de la conservación del arte contemporáneo. La creación en 1995 de The Foundation for the Conservation of Contemporary Art, (De Stichting Behoud Moderne Kunst, SBMK), ha impulsado diferentes proyectos de investigación, destacando sobre todo el International Network for the Conservation of Contemporary Art, (INCCA) creado en 1999 o el proyecto Modern Art: Who Cares? culminando en un congreso internacional celebrado en 1998 (Hummelen 1999).

Modern Art: Who Cares? priorizó la metodología cualitativa, poniendo el foco en la documentación, la intención del artista y el significado de los materiales en las obras de arte contemporáneo. Se analizaron once casos de estudio de obras contemporáneas que presentaban gran dificultad ética y teórica, y se reflexionó sobre la metodología y criterio de actuación en este campo. Además, este congreso supuso una publicación de referencia en la toma de decisiones en arte contemporáneo.

Cabe mencionar cómo los proyectos de investigación internacionales a finales del siglo XX han derivado en un tipo de trabajo colaborativo e interdisciplinar entre los diferentes centros profesionales e instituciones de distintos países, tales como los proyectos de investigación organizados por INCCA con el proyecto Inside Installations (2004-2007), o el proyecto PRACTICs of Contemporary Art: The Future (2009-2011).

En el 2010 se realizó en Amsterdam el simposio Contemporary Art, Who Cares?, (congreso del que no se publicaron actas, pero sí existe amplia información en la web del SBMK), que se trataría sin duda de la continuación del proyecto iniciado con Modern Art, Who Cares? (Hummelen 1999). En ambos encuentros y como figura destacada dentro del Netherlands Institute for Cultural Heritage (ICN) es importante señalar para configurar el panorama internacional, la figura del investigador y filósofo IJsbrand Hummelen.

En el ámbito holandés y desde la Faculty of Arts and Social Science at Maastricht University se desarrolló en el 2019 el encuentro: Bridging the Gap. Theory and Practice in the the Nara Document, it is mentioned how other factors beyond the material and historical have to be taken into account. That different values must be taken into account: "depending on the nature of the cultural heritage, its cultural context, and its evolution over time, authenticity judgments may relate to the validity of a wide variety of sources of information. Aspects of the sources may include form and design, materials and substance, use and function, traditions and techniques, location and context, spirit and feeling, and other interior and exterior factors". (ICOMOS 1994).

On the other hand, the professional landscape in the field of contemporary art restoration took a significant boost in 1993, when the Dutch museums specialised in contemporary art decided to join forces to research the issues related to the problems of contemporary art conservation. The creation in 1995 of the Foundation for the Conservation of Contemporary Art (De Stichting Behoud Moderne Kunst, SBMK) has given impetus to various research projects, notably the International Network for the Conservation of Contemporary Art (INCCA) created in 1999, and the project Modern Art: Who Cares?, culminating in an international congress held in 1998 (Hummelen 1999).

Modern Art: Who Cares? prioritised qualitative methodology, focusing on documentation, the artist's intention, and materials' meaning in contemporary works of art. Eleven case studies of ethically and theoretically challenging contemporary artworks were analysed, and they reflected upon the methodology and criteria for action in this field. In addition, this congress became a reference publication in decisionmaking in contemporary art.

It is worth mentioning how international research projects at the end of the 20th century have led to collaborative and interdisciplinary work between different professional centres and institutions in different countries. Such as the research projects organised by INCCA with the Inside Installations project (2004-2007) or the PRACTICes of Contemporary Art: The Future project (2009-2011).

In 2010, the symposium Contemporary Art, Who Cares? was held in Amsterdam (the proceedings have not been published, but there is ample information on the SBMK website), which was undoubtedly a continuation of the project initiated with Modern Art, Who Cares? (Hummelen 1999). In both meetings, and as a leading figure within the Netherlands Institute for Cultural Heritage (ICN), it is essential to point out the researcher and philosopher IJsbrand Hummelen's figure to configure the international panorama.

In the Dutch sphere and from the Faculty of Arts and Social Science at Maastricht University, the meeting Bridging the Gap. Theory and Practice in the Conservation 
Conservation of Contemporary Art (NACCA 2019) (http:// nacca.eu/conference-2019/) donde destacaron importantes conferencias como la de Tomas Markevicius (Markevicius 2019). De ahí surgió un interesante documento que abordaba la revisión crítica y actualización del modelo de toma de decisiones generado hacía ya veinte años, (TH Köln, 2019).

En este contexto, en Holanda, se desarrolló un programa (desde 2015 a 2019), llamado: New Approaches in the Conservation of Contemporary Art (NACCA), coordinado por la Faculty of Arts and Social Sciences at Maastricht University donde se desarrollaron importantes investigaciones sobre distintos aspectos teóricos de la obra de arte contemporánea y su conservación, destacando un proyecto de investigación sobre Identity, Authenticity and Values ${ }^{[3]}$.

Son muchísimos los autores que se han preocupado por la conservación y restauración del arte contemporáneo desde una perspectiva teórica y metodológica, y aunque el debate se inició en Alemania con Heinz Althöfer, ya en sus primeras aportaciones teóricas manifestó la necesidad de preservar la intención del artista, conociéndola a través de cuestionarios a artistas y el apoyo de la documentación exhaustiva de la obra, subrayando la importancia del nivel simbólico de los materiales y del mensaje que se quería preservar para mantener viva la obra de arte (Althöfer 1960). Distinguía dos tipos de áreas de investigación: por un lado, las dificultades técnicas y por otro los fundamentos teóricos e ideológicos, siendo claves en esta última dos aspectos: la originalidad y la autenticidad en el arte moderno como una cuestión para indagar en el campo de la restauración (Althöfer 1977). En Italia también, en la investigación teórica, destaca la historiadora del arte y conservadora-restauradora Marina Pugliese, que ahonda sobre la restauración de las instalaciones (Pugliese y Ferriani 2009), cuya importancia radica en saber analizar transversalmente los casos prácticos planteados, poniendo luz conceptual a la metodología a seguir en las restauraciones de este tipo de manifestaciones artísticas de arte contemporáneo. Es reseñable cómo en el ámbito italiano la reflexión teórica con relación a los criterios de restauración del arte contemporáneo siempre estuvo a la cabeza, destacando numerosos autores Dezzi Bardeschi (Bardeschi 2004) o las aportaciones de Francesca Valentini, (Valentini 2010).

En el ámbito germano y siguiendo las enseñanzas de su maestro Heinz Althöfer, en el centro de restauración de Düsseldorf, destaca el corpus teórico de la restauradora Hiltrud Schinzel, que ahonda de manera muy interesante en distintas cuestiones teóricas como la intencionalidad, la autenticidad y la originalidad, siempre desde un enfoque fenomenológico. (Schinzel 2002; 2004a; 2004b). Por otro lado, en el ámbito polaco también destacan autoras como Iwona Szmelter (Szmelter 1999; 2012) o Jadzinska, ambas profesoras de la universidad de Varsovia. (Jadzinska 2008; 2012), que desarrollan un corpus teórico que parte de las teorías brandianas y que enlazan con las teorías más actuales desarrolladas en Holanda, en el seno del SBMK. of Contemporary Art (NACCA 2019) (http://nacca.eu/ conference-2019/) where important lectures such as Tomas Markevicius (Markevicius 2019) stood out. It resulted in an exciting document that addressed the critical revision and updating of the decision-making model generated twenty years ago (TH Köln 2019).

In this context, in the Netherlands, a programme was developed (from 2015 to 2019), called: New Approaches in the Conservation of Contemporary Art (NACCA), coordinated by the Faculty of Arts and Social Sciences at Maastricht University. This included vital research on different theoretical aspects of the contemporary work of art and its conservation, highlighting a research project on Identity, Authenticity and Values ${ }^{[3]}$.

Many authors have been concerned with the conservation and restoration of contemporary art from a theoretical and methodological perspective. Although the debate began in Germany with Heinz Althöfer. Yet in his first theoretical contributions, he expressed the need to preserve the artist's intention, knowing it through questionnaires to artists and the support of exhaustive documentation of the work, stressing the importance of the symbolic level of the materials and the message to be preserved in order to keep the work of art alive (Althöfer 1960). He distinguished two types of research areas: the technical difficulties and the theoretical and ideological foundations. In the latter, two aspects were: originality and authenticity in modern art as a question to be investigated in the field of restoration (Althöfer 1977). Also, in Italy, in theoretical research, the art historian and conservator Marina Pugliese made important contributions to the topic. Her in-depth study of the restoration of installations (Pugliese and Ferriani 2009) showed how to analyse the practical cases raised transversally, sheded conceptual light on the methodology to be followed to restore this type of artistic manifestations of contemporary art. In the Italian sphere, it is noteworthy that theoretical reflection on the criteria for the conservation of contemporary art has always been at the forefront, with numerous authors such as Dezzi Bardeschi (Bardeschi 2004) or the contributions of Francesca Valentini (Valentini 2010) standing out.

In the German sphere, and following the teachings of her teacher Heinz Althöfer, at the Düsseldorf restoration centre, the theoretical corpus of the restorer Hiltrud Schinzel can be highlighted. Schinzel delves in an exciting way into different theoretical questions such as intentionality, authenticity, and originality, always from a phenomenological approach (Schinzel 2002; 2004a; 2004b). Also, authors such as Iwona Szmelter (Szmelter 1999; 2012) or Jadzinska, both professors at the University of Warsaw, stand out in the Polish field (Jadzinska 2008; 2012). They developed a theoretical corpus based on Brandian theories and linked them with the most current theories developed in Holland, within the SBMK. 


\section{Metodología}

Ante la cuestión que se presenta en el título de este artículo, ¿qué conservar en el arte contemporáneo?, nos debemos hacer otras preguntas intrínsecamente relacionadas: ¿existe una teoría de la restauración del arte contemporáneo?, ¿cuál es el panorama actual en la toma de decisiones? y ¿qué debe prevalecer: ¿la conservación de la materia original, el aspecto final o el mensaje conceptual de la obra?

Como punto de partida respecto a dónde reside la autenticidad, en primer lugar, podemos aseverar que no se trata de algo unívoco y universal ya que se trata de un valor cultural, por lo que no podemos aceptar la unidad de criterios para todo el Patrimonio, la heterogeneidad contextual posee diferentes matices y valores, por lo que no puede ser aplicado de forma idéntica en distintos ámbitos culturales ni en distintos tipos de patrimonio. De hecho, en 2005, la UNESCO extendió este criterio para incluir más categorías, en las llamadas condiciones de autenticidad en el Test of Authenticity ${ }^{[4]}$, donde la autenticidad dependía de valores como la función, la forma y el diseño, los materiales y las sustancias, las tradiciones y las técnicas, el lugar y el contexto, la idea, el espíritu y el sentimiento, la energía y otros factores internos y externos. Por lo que podemos observar, la conservación de la autenticidad de la obra de arte se ha vuelto algo mucho más complejo que la mera conservación de la estructura material y el estado original.

Llegados a este punto, si nos preguntamos qué determina la autenticidad de un objeto, qué lo define y cómo debe ser conservado, la cuestión radica en si la pérdida o cambios en alguna parte de la obra modifica el significado de la obra y su apreciación como obra de arte, es decir, si su definición como arte depende de la estructura material del objeto, o de la idea a partir de la que fue creada.

\section{Pérdida de valor de la materia original y el mensaje}

En el arte contemporáneo la materia adquiere un valor diferente al arte tradicional, deja de ser en muchos casos soporte de la imagen como forma representada para ser soporte de significados y valores, de este modo para conservar la autenticidad de la obra de arte ya no sólo deberemos respetar el material original como documento histórico, sino como creación que expresa las intenciones conceptuales del artista.

Podríamos citar muchos ejemplos sobre la cuestión, pero sin duda los casos de arte conceptual son los que más evidencian la situación actual, por ejemplo la obra Akwarel, nr 64-7 de Henk Peeters, (1965) donde la obra consiste en una composición de bolsas de plástico rellenas de agua [Figura 2]. En el caso de romperse alguna de las bolsas, serían repuestas sin dilación. (Hummelen 2006).

Se podrían citar infinidad de casos que siguen este nuevo principio teórico, como son las obras de Naum Gabo,

\section{Methodology}

Faced with the question presented in the title of this article, what to conserve in contemporary art?, we must ask ourselves other intrinsically related questions: Is there a theory of contemporary art conservation? What is the current panorama in decision-making? and last but not least, what should prevail: the conservation of the original material, the final appearance, or the conceptual message of the artwork?

As a starting point as to where authenticity resides, we can first assert that it is not something univocal and universal. Since it is a cultural value, we cannot accept the unity of criteria for all Heritage. The contextual heterogeneity has different nuances and values, so it cannot apply identically in different cultural spheres or different types of Heritage. In fact, in 2005, UNESCO extended this criterion to include more categories in the so-called conditions of authenticity in the Test of Authenticity ${ }^{[4]}$. Authenticity depends on functions, form and design, materials and substances, traditions and techniques, place and context, idea, spirit and feeling, energy, and other internal and external factors. As far as we can see, the preservation of the authenticity of an artwork has become much more complex than the mere preservation of the material structure and the original state.

At this point, the question arises as to what determines an object's authenticity, what defines it, and how it should be preserved. The question is whether loss or alterations to any part of the work changes the meaning of the work and its appreciation as a work of art, i.e., whether its definition as art depends on the object's material structure or on the idea from which it was created.

\section{Loss of value of the original material and the message}

In contemporary art, the material acquires a different value from traditional art, as in many cases, it ceases to support the image as a represented form and becomes a support for meanings and values. In this way, to preserve the authenticity of an artwork, we must respect the original material as a historical document and as a creation that expresses the artist's conceptual intentions.

We could cite many examples on the question. Still, without doubt, the cases of conceptual art are the ones that most demonstrate the current situation. For example, the artwork Akwarel, $n r$ 64-7 by Henk Peeters (1965) which consists of a composition of plastic bags filled with water [Figure 2]. If any of the bags were to break, they would be replaced without delay (Hummelen 2006).

Following this new theoretical principle, we find, for instance, the works of Naum Gabo, constructed from 
construidas a partir de hilos de nylon y que son sustituidos para mantener la composición visual y la estética traslúcida que presentaba la obra en origen, (no olvidemos que el nylon se vuelve quebradizo y amarillea con el tiempo). Por otro lado, en esta línea de actuación podemos citar también todas las obras cinéticas y tecnológicas, en las que los componentes de las mismas deben ser sustituidos para conseguir el "funcionamiento" de la obra, es decir, continuar activa la intencionalidad con la que fue creada, bien sea de movimiento, de luz o de sonido.

Con relación a la práctica de la restauración observamos cómo se llegan a realizar copias de las obras originales degradadas para recuperar una estética determinada o porque la degradación las ha destruido casi por completo. Por otro lado, y en contraposición a lo anterior, existen también obras donde el material adquiere nuevos valores relacionados con la semántica del lenguaje artístico, tal y como sucede en el Arte Povera, o en determinadas obras de Tony Cragg o Joseph Beuys, donde la sustitución del material original supondría la pérdida total de la obra. nylon threads that are substituted to maintain the visual composition and translucent aesthetic that the work presented initially (let us not forget that nylon becomes brittle and yellows with time). In this line of action, we can also mention all kinetic and technological works, in which their components must be replaced in order to achieve the "functioning" part of the work. This is to maintain the active intentionality with which the artwork was created, being movement, light, or sound.

Concerning conservation practice, we observe how copies of degraded original works are made to recover a specific aesthetic or because the degradation has almost completely destroyed them. In contrast to the above, there are also works where the material acquires new values related to the semantics of the artistic language, as happens in Arte Povera, or in certain works by Tony Cragg or Joseph Beuys, where the replacement of the original material would mean the total loss of the work.

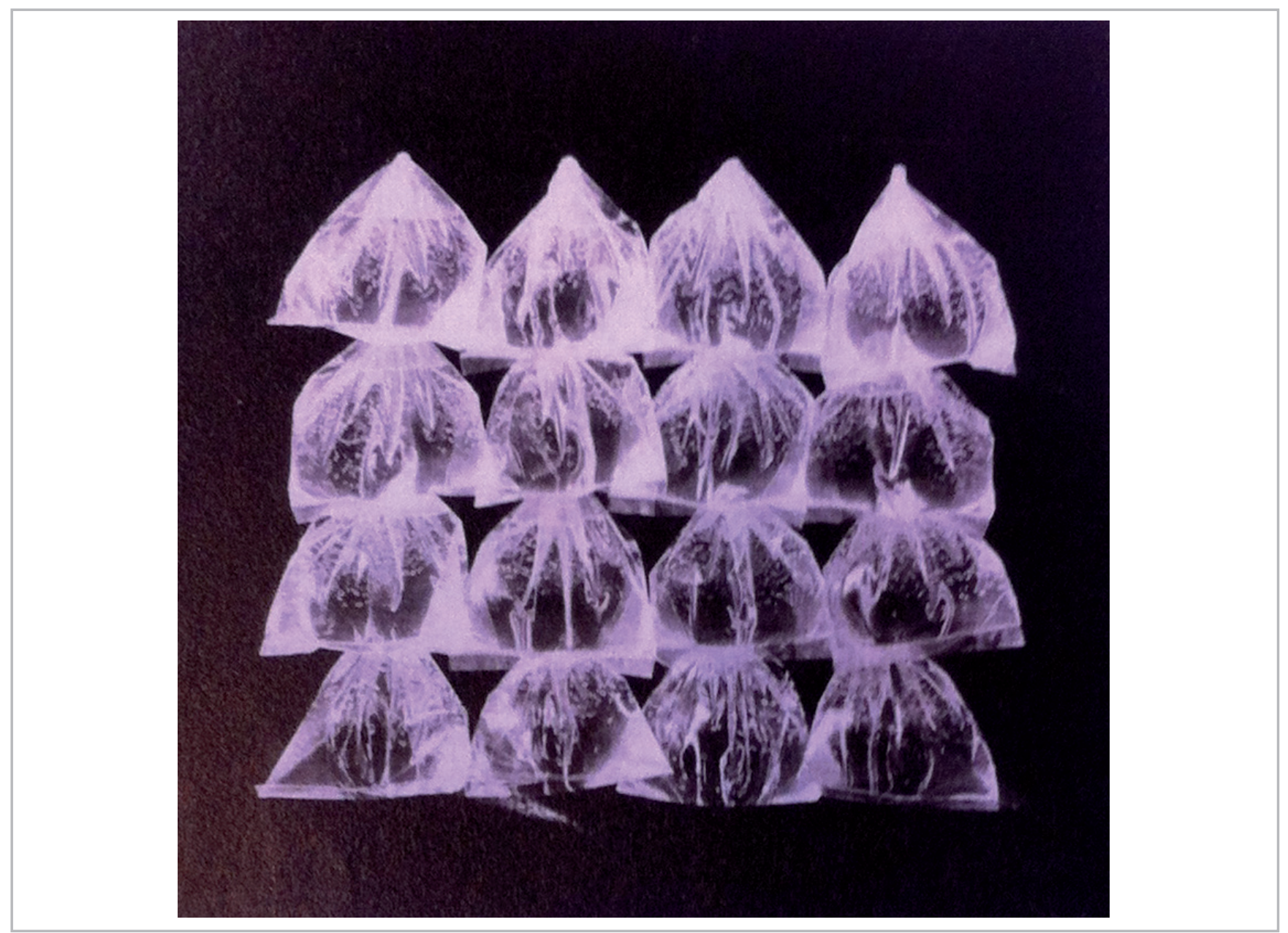

Figura/Figure 2.- IJ. Hummelen. Conception, creation and re-creation. Embodied Knowledge and the preservation of contemporary art. en: Delgado, J. Mimoso, J.M. International Seminar. Theory and Practice in Conservation. National Laboratory of Civil engineering. Lisbon. 2006. p. 30 (Figura 2: Henk Peeters: Akwarel, nr. 64-7 (1965), 50 x 50 cm. Prototype, plastic bags, water. Colección del artista. Photo by Truus Nienhuis.) / IJ. Hummelen. Conception, creation and re-creation. Embodied Knowledge and the preservation of contemporary art. in: Delgado, J. Mimoso, J.M. International Seminar. Theory and Practice in Conservation. National Laboratory of Civil engineering. Lisbon. 2006. p. 30 (Figure 2: Henk Peeters: Akwarel, nr. 64-7 (1965), 50 x 50 cm. Prototype, plastic bags, water. Collection of the artist. Photo by Truus Nienhuis. 
Según Antonio Rava, hay obras que pueden ser rehechas mediante la ejecución diferida siempre que el proyecto y el artista no haya ejecutado con sus propias manos la obra de arte. Sin embargo, no se podrá rehacer la obra si no existe la documentación gráfica necesaria para testificar cómo era en origen.

Sin embargo, en otras ocasiones, no nos quedará más remedio que la aceptación de la degradación material, incluso cuando la creación y experimentación artística lleve consigo la innovación material y técnica con pésimos resultados a nivel de conservación. Tal es el caso de las obras realizadas con plásticos de diferente índole. En estos casos la sustitución del original degradado por una versión actualizada no siempre será posible, a veces se trata de obras autógrafas cuya réplica no dejaría de ser una falsificación. Como es el caso de Still Life of watermelons (1996) de Piero Giraldi.

Schinzel plantea que ante una obra de arte contemporáneo debemos plantearnos, como metodología para saber cómo actuar, para quién restauramos y, por ende, decidir cuál es el valor primordial que deseamos conservar del arte: si la materia o la idea que reside en ella. Si, por un lado, lo más importante es la materia y la conservamos, estaremos restaurando esa obra de arte para el futuro, pero si por el contrario, la idea que permanece en la obra es lo más importante y hacemos todo lo posible para que perdure, debemos ser conscientes que estaremos conservando el arte para nuestros contemporáneos. Es decir, cuando restauramos debemos ser conscientes de que no solo restauramos el material, sino también la entidad visual fáctica: material, técnica y medio. En el caso de que nos cuestionemos dónde reside el valor del objeto a restaurar, para Schinzel, recae en la originalidad y la totalidad de poder leer el mensaje original. Para ella, la autenticidad es lo que convierte a la obra de arte en única, genial e irrepetible, transformando el arte en modelo y paradigma para expresar estados del hombre e ideas. En el pensamiento de Schinzel destaca también el concepto de originalidad el cual surge cuando se cuestiona por qué restaurar y en tal caso, qué valor tiene el objeto a restaurar. Según afirma:

"La originalidad radica en la totalidad, es decir leer el mensaje de la idea original de la obra de arte sólo en su totalidad. La originalidad engloba tanto el significado de autenticidad como de no falsificación. Finalmente, el concepto de originalidad contiene un valor que distingue una obra de arte como única, genial, irrepetible y perfecta." (Schinzel, H. 2000).

En el ámbito europeo, concretamente en Polonia, Szmelter defiende la necesidad de un nuevo marco conceptual teórico para la preservación, conservación y restauración, manteniendo la custodia del patrimonio cultural, tanto el tangible como el intangible.

Ya en el congreso Modern Art, who cares? (Szmelter 1999: 322-326), la restauradora polaca planteaba aunar una serie de problemas que atañen al arte contemporáneo, tales
According to Antonio Rava, there are artworks that can be remade through deferred execution as long as the project and the artist have not executed the artwork with his own hands. However, it cannot be remade if the necessary graphic documentation does not exist to testify to its original state.

However, we will have no choice but to accept material degradation, even when artistic creation and experimentation entails material and technical innovation with terrible results in terms of conservation. Such is the case of works made with plastics of different kinds. In these cases, replacing the degraded original with an updated version is not always possible; sometimes, they are autograph works whose replica would still be a forgery. This is the case of Piero Giraldi's Still Life of watermelons (1996).

Schinzel suggests that when faced with a contemporary artwork, we must ask ourselves as a methodology to know. How to act, for whom we are restoring, and therefore, decide the primary value we wish to conserve in art: whether it is the material or the idea that resides in it. If the most important thing is the material and we conserve it, we will be restoring that artwork for the future. Still, if the idea that remains in the piece is the most important thing and we do everything possible to make it last, we must be aware that we will be conserving art for our contemporaries. That is to say that when we conserve an artwork, we must be mindful that we are not only conserving the physical but also the factual visual entity: material, technique, and medium. In the case that we question where the value of the object to be restored lies, for Schinzel, it lies in the originality and the completeness of being able to read the original message. For her, authenticity makes the work of art unique, brilliant, and unrepeatable, transforming art into a model and paradigm for expressing states of man and ideas. Schinzel's thinking also emphasises the concept of originality, which arises when she questions why conserve and if so, what is the value of the object to be conserved. As she states:

"Originality lies in the totality, i.e. reading the message of the original idea of the work of art only in its totality. Originality encompasses both the meaning of authenticity and non-forgery. Finally, the concept of originality contains a value that distinguishes a work of art as unique, brilliant, unrepeatable and perfect". (Schinzel 2000).

At the European level, specifically in Poland, Szmelter defends the need for a new theoretical, conceptual framework for preservation, conservation and restoration, maintaining the custody of cultural heritage, both tangible and intangible.

At the conference Modern Art, who cares?, Szmelter proposed to bring together a series of problems that concern contemporary art, such as: difficulties 
como: las dificultades para la identificación del significado de los objetos, la recolección de información y el contacto con los artistas; la dificultades técnicas con la preservación de las superficies perfectas y sin restaurar; los problemas con la identificación de los materiales constituyentes, así como el alto coste que conlleva el examen de los mismos con equipamientos de alta tecnología, y la colaboración con personal altamente especializado, los dilemas éticos concernientes a la conservación y la sustitución del readymade, y los objetos degradables compuestos de material orgánico, como comida, huesos, plantas, o materiales no durables (Szmelter 1999: 322-326).

La toma de decisiones conservativas se basaría entonces en la documentación, donde el objeto es destruido y registrado como arte efímero, como un proceso performativo que puede ser reproducido. Su propuesta teórica se basa en una visión más amplia de la preservación y apreciación del arte, desde una perspectiva interdisciplinar, abarcando lo tangible e intangible, sobrepasando la concepción del arte clásico. Plantea la realización de un esfuerzo holístico para transmitir los logros humanos a las sucesivas generaciones, teniendo en consideración los elementos materiales y los no materiales.

\section{Un nuevo modelo de toma de decisiones}

Según Hummelen "La representación de la idea es vista como una derivación de la práctica artística. Sin embargo, hay un componente de la conservación del arte occidental basado en la recopilación de documentación de una obra que es algo relativamente reciente". (Hummelen 2006:28). Por lo tanto, la conservación del arte contemporáneo no implicará la conservación directa del objeto físico sino otro tipo de operaciones que lleven a la conservación de la memoria de esa estética-cultural. Es fundamental averiguar cómo se relaciona simbólicamente entre la materialidad resultante y el concepto original de la obra.

A instancia de este teórico holandés se creó un modelo de toma de decisiones en 1999, en el SBMK, (Hummelen 1999) [Figure 3], que consistía en un diagrama de flujo de 7 pasos que estaban subordinados para alcanzar una decisión óptima a la hora de intervenir. En una primera fase estaban las cuestiones relacionadas con el registro de información, la condición de la obra de arte y su significado. A continuación, se generaban una serie de preguntas en cuanto a las discrepancias que se podían generar entre estas últimas, es decir si la alteración de la obra y su degradación había alterado su significado. En un quinto paso estarían las opciones de conservación-restauración potencialmente planteables, que podían variar desde sencillas, abiertas y flexibles, a una segunda opción de la generación de nuevas preguntas y en una tercera opción que revelaba que la puesta en relación entre el estado de conservación y el significado había generado problemas de restauración de gran importancia. Una vez planteadas las consideraciones se haría la propuesta de tratamiento que se había decidido. Veinte años después, en el 2019, se ha visto la necesidad in identifying the meaning of objects, collecting information and contacting artists, technical difficulties with the preservation of perfect and unrestored surfaces, problems with the identification of constituent materials, as well as the high cost of examining them with high-tech equipment and collaboration with highly specialised personnel, ethical dilemmas concerning the conservation and replacement of the ready-made, and last but not least, degradable objects composed of organic material, such as food, bones, plants, or non-durable materials (Szmelter 1999: 322326).

Conservation decision-making would then be based on documentation, where the object is destroyed and recorded as ephemeral art, a performative process that can be reproduced. His theoretical proposal is based on a broader vision of the preservation and appreciation of art from an interdisciplinary perspective, encompassing the tangible and intangible, surpassing the conception of classical art. It calls for a holistic effort to transmit human achievements to successive generations, considering both material and non-material elements.

\section{A new decision-making model}

According to Hummelen, "The representation of the idea is seen as a derivation of artistic practice. However, there is a component of Western art conservation based on the collection of documentation of a work that is a relatively recent development" (2006:28). Therefore, the conservation of contemporary art will not involve the immediate preservation of the physical object but other types of operations that lead to the conservation of the memory of that cultural aesthetic. It is essential to find out how the resulting materiality is symbolically related to the original artwork's concept.

At the behest of this Dutch theorist, a decision-making model was created in 1999 at the SBMK (Hummelen 1999) [Figure 3], which consisted of a flow chart of seven subordinate steps to reach an optimal decision to intervene. In the first step, there were questions related to the recording of information, the artwork's condition, and its meaning. This was followed by a series of questions (steps 2 to 4 ) regarding the discrepancies that could be generated between the latter (i.e. whether the alteration of the work of art and its degradation had altered its meaning). A fifth step would be the potential conservation-restoration options, which could vary from simple, open and flexible, to a second option of generating new questions and a third option that revealed that the relationship between the state of conservation and meaning had developed major restoration problems. Once the considerations had been raised (step 6), the treatment proposal that had been decided would be made (step 7). Twenty years later, in 2019, the need to revise this decision-making 
de revisar este modelo de toma de decisiones, de tal modo se generó un documento desde el Cologne Institute of Conservation Sciences / TH Köln. [Figura 4]

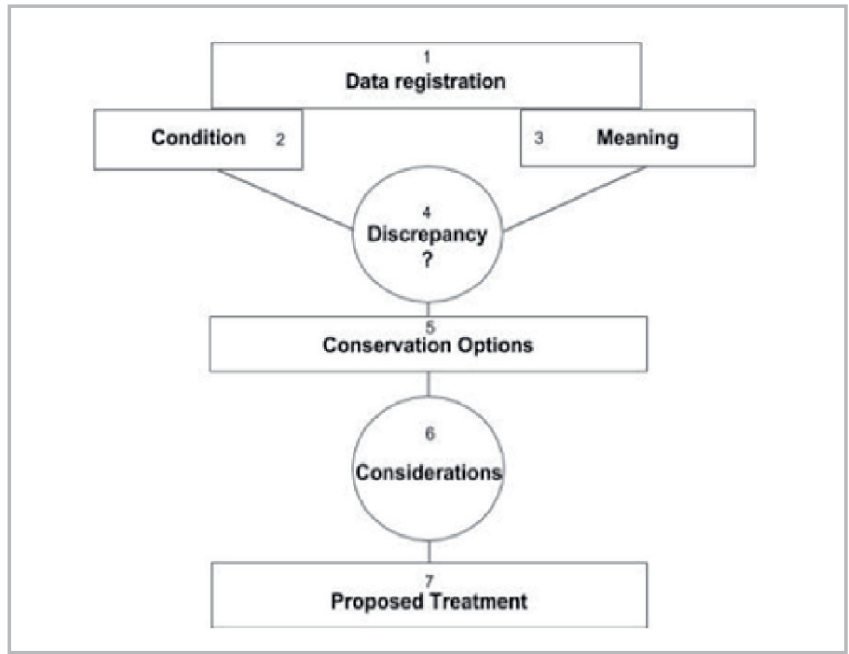

Figura/Figure 3.- Modelo de toma de decisiones para la conservation y restauracion para Arte Moderno y Contemporáneo, SBMK 1999. / The decision-making Model for the conservation and restoration of Modern and Contemporary Art, SBMK 1999.

En este nuevo modelo de toma de decisiones, para elegir un criterio de restauración, se tuvieron en cuenta cuestiones intangibles, más allá del aspecto material de la obra y la investigación científica, atendiendo a lo que viene a ser la propia definición de la obra de arte y la evolución conceptual de la misma en la última década, así como, la necesidad de reflexionar sobre la importancia de un modelo de toma de decisiones en la conservación del arte contemporáneo, valorando la subjetividad y la situación dinámica al respecto, así como el desarrollo de la terminología al respecto en la conservación del arte contemporáneo. Este nuevo modelo estaría focalizado, no tanto en la búsqueda de un tratamiento de restauración en sí mismo, sino en la valoración e implementación de una estrategia de conservación, siendo conscientes de que la obra de arte no es un hecho aislado en el tiempo sino que está sometido a una evolución contextual, con el pasado y con el futuro, generando una evolución en su propia identidad a lo largo del tiempo y por lo tanto, generando puntos de inflexión en esas estrategias que pueden ir variando a lo largo de la vida de la obra.

\section{Conclusión}

En relación a las cuestiones planteadas más arriba, se puede constatar cómo los diferentes planteamientos teóricos sobre conservación de arte contemporáneo se remiten a la búsqueda de diferentes conceptos que definan la obra de arte, tales como: el aspecto visual y el histórico, y a otros conceptos más actuales como la funcionalidad, la opinión del artista, la historicidad, la documentación, la identidad y la importancia de la obra de arte, así como las limitaciones económicas, los aspectos legales y las limitaciones técnicas, siempre basándose en un código model was identified, and a document was produced by the Cologne Institute of Conservation Sciences / TH Köln [Figure 4].

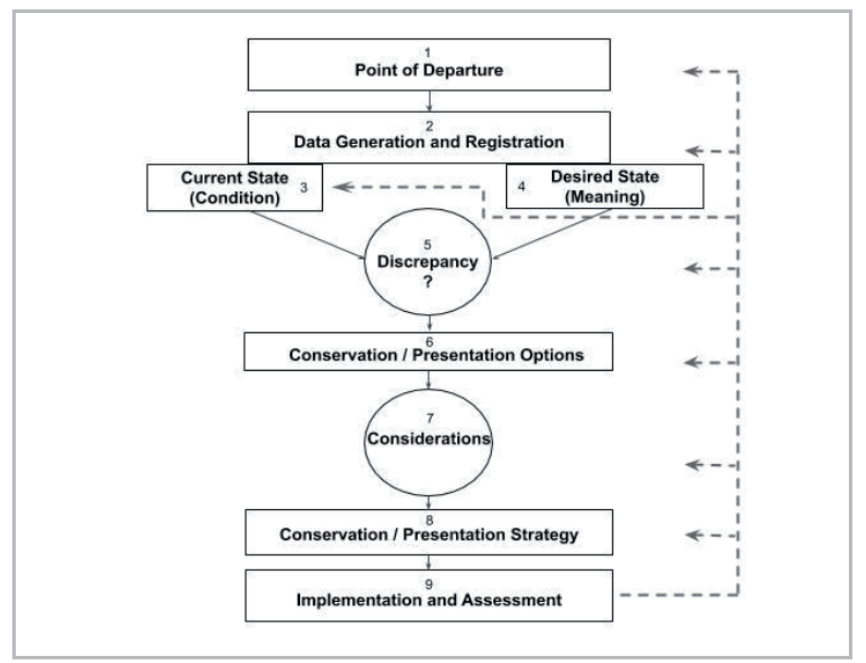

Figura/Figure 4.- Modelo de toma de decisiones para la conservation de Arte Contemporáneo, TH Köln, 2019. / The Decision-Making Model for Contemporary Art Conservation and Presentation, TH Köln, 2019.

In this new decision-making model, to choose a conservation criterion, intangible issues were considered beyond the material aspect of the work and scientific research. They are considering the definition of the work of art itself and its conceptual evolution over the last decade. It is also considered the need to reflect on the importance of a decision-making model in the conservation of contemporary art, valuing subjectivity and the dynamic situation in this respect, as well as the development of terminology in this respect in the preservation of contemporary art. This new model would focus not on searching for a conservation treatment but on evaluating and implementing a conservation strategy. Conscient that the work of art is not an isolated fact in time but is subject to a contextual evolution, with the past and the future generating a change in its own identity over time and therefore generating turning points in these strategies that may vary throughout the life of the work.

\section{Conclusion}

The questions raised above show how the different theoretical approaches to contemporaryartconservation refer to the search for different concepts that define the work of art, such as the visual and historical aspects. Other more current concepts such as functionality, the artist's opinion, historicity, documentation, identity, and the artwork's importance, economic limitations, legal aspects, and technical limitations, are always based on an ethical code of ethics of the conservator's profession. 
deontológico ético de la profesión del conservador-restaurador. No podemos perder de vista que la definición de los límites de la autenticidad en el cuidado del patrimonio cultural ha de ser valorada según la época y el contexto y por ello debemos analizar conceptos, no sólo como la autenticidad, sino otros como la identidad, que sería más adecuado para definir el legado cultural contemporáneo, y que hace referencia en términos ontológicos a los valores que encierra la obra de arte.

Vemos, por lo tanto, que si pretendemos responder a la pregunta ¿qué conservamos? no podemos dar una respuesta unívoca y automática, sino que el trabajo del conservadorrestaurador consistirá en un arduo trabajo de investigación sobre la trayectoria del autor, el contexto cultural y artístico, la historia material de la obra y la recopilación de fuentes, así como la consideración de opiniones y directrices del autor, si está vivo o de los depositarios de los derechos morales del mismo. Así como la valoración de distintos factores que pueden influir en la toma de decisiones, desde el significado, el aspecto o la originalidad, así como la experiencia que debe generar en el público a nivel sensorial. Por ello la valoración de todos esos factores valorados y enfrentados en discusión dialéctica, llevarán a la adopción de una metodología, que se enmarque en la actuación dentro de los parámetros del código deontológico de la profesión y del respeto al arte en su razón de ser, para entenderlo mejor, mantenerlo vivo y transmitirlo al futuro.

\section{Notas}

[1] REAL DECRETO LEGISLATIVO 1/1996, de 12 de abril BOE núm. 97, de 22/04/1996. BOE núm. 97, de 22/04/1996. BOE-A-1996-8930. Según el artículo 26 del vigente Texto Refundido de la Ley de Propiedad Intelectual: "Los derechos de explotación de la obra durarán toda la vida del autor y setenta años después de su muerte o declaración de fallecimiento" (Real Decreto Legislativo 1/1996, de 12 de abril BOE núm. 97, de 22/04/1996).

[2] El documento de Nara en autenticidad fue resultado de la Conferencia de Nara en autenticidad respecto a la Convención del Patrimonio mundial. Nara, Japón de 1 al 6 de noviembre de 1994, a instancias de la Agencia de Asuntos Culturales (Gobierno de Japón) y de la Prefectura de Nara. La Agencia organizó la Conferencia de Nara en cooperación con la UNESCO, el ICCROM y el ICOMOS

[3] Engloba los siguientes proyectos: 1 Mapping Critical Mass: Authenticity in Remanifestations of Contemporary Artworks, (Researcher: Brian Castriota, Affiliation: University of Glasgow); 2 Values and Valuation of Modern and Contemporary Visual Art: The Role of Reflective Practice (Researcher: Joanna Kiliszek, Affiliation: Academy of Fine Arts, Warsaw); 3 The Artist Intent in Contemporary Art: Matter and Process in Transition (Researcher: Nina Quabeck, Affiliation: University of Glasgow); 4 The Role of Conservation Sciences in the Authentication of Modern and Contemporary Art Works (Researcher: Tomas Markevicius, Affiliation: Cologne University of Applied Sciences); 5 Authenticity and Reproducibility: Conservation Strategies for Contemporary Photography (Researcher: Marta Garcia Celma, Affiliation: Cologne University of Applied Sciences); 6 Conservation Strategies for Computer-Based Artworks (Researcher:
We cannot lose sight of the fact that the definition of the limits of authenticity in the care of cultural heritage has to be assessed according to the period and the context. Therefore, we must analyse concepts, such as authenticity and others, such as identity, which would be more appropriate to define the contemporary cultural legacy, which refers in ontological terms to the values contained in the work of art.

In addition, we see that if we try to answer the question "what do we conserve?" as we cannot give a univocal and automatic answer. The work of the conservator will consist of arduous research work on the trajectory of the author, the context (cultural and artistic), the material history of the work, and the collection of sources. It also needed to consider the opinions and guidelines of the artist, if they are alive, or of the holders of the artist's moral rights (their state). Alongside the assessment of different factors that may influence the decision making, from the meaning, appearance or originality, as well as the experience it should generate in the audience on a sensory level. In consequence, the assessment of all these factors, evaluated and confronted in the dialectic discussion, will lead to the adoption of a methodology that is framed within the parameters of the code of ethics of the profession and respect for art in its raison d'être, in order to better understand it, keep it alive and transmit it to the future.

\section{Notes}

[1] ROYAL LEGISLATIVE DECREE 1/1996, of 12 April 1996, BOE No. 97, of 22/04/1996. BOE No. 97, of 22/04/1996. BOE-A-1996-8930. According to article 26 of the current Revised Text of the Law on Intellectual Property: "The exploitation rights of the work shall last for the whole life of the author and seventy years after his death or declaration of death" (Royal Legislative Decree 1/1996, of 12 April, BOE no. 97, of 22/04/1996).

[2] The Nara Document on Authenticity was the result of the Nara Conference on Authenticity with respect to the World Heritage Convention. Nara, Japan from 1 to 6 November 1994, at the request of the Agency for Cultural Affairs (Government of Japan) and Nara Prefecture. The Agency organised the Nara Conference in cooperation with UNESCO, ICCROM and ICOMOS

[3] It includes the following projects: 1 Mapping Critical Mass: Authenticity in Remanifestations of Contemporary Artworks, (Researcher: Brian Castriota, Affiliation: University of Glasgow); 2 Values and Valuation of Modern and Contemporary Visual Art: The Role of Reflective Practice (Researcher: Joanna Kiliszek, Affiliation: Academy of Fine Arts, Warsaw); 3 The Artist Intent in Contemporary Art: Matter and Process in Transition (Researcher: Nina Quabeck, Affiliation: University of Glasgow); 4 The Role of Conservation Sciences in the Authentication of Modern and Contemporary Art Works (Researcher: Tomas Markevicius, Affiliation: Cologne University of Applied Sciences); 5 Authenticity and Reproducibility: Conservation Strategies for Contemporary Photography (Researcher: Marta Garcia Celma, Affiliation: Cologne University of Applied Sciences); 6 Conservation 
Claudia Röck, Affiliation: University of Amsterdam); 7 Conservation of Contemporary Art and Ethnographic Materials: Relationships, Similarities and Differences (Researcher: Caitlin Spangler-Bickell, Affiliation: Maastricht University \& MUDEC Milan); 8 The Exhibition as a Conservation Tool: Examining Changes in Presentation Discourses and Practices (Researcher: Panda de Haan, Affiliation: University of Porto); 9 Artist Interviews and Artist Participation as Research Tools in Conservation Practices, (Researcher: Aga Wielocha, Affiliation: University of Amsterdam); 10 Audience Participation in Performance-based Art (Researcher: Iona Goldie-Scot, Affiliation: Maastricht University); 11 Database for the Documentation of Contemporary Art (Researcher: Dušan Barok, Affiliation: University of Amsterdam); 12 Contemporary Art Conservators and Curators: Roles, Collaboration, Training and Ethics (Researcher: Maria Theodoraki, Affiliation: Universidade Nova de Lisboa); 13 On the Artists' Side: Bridging the Gap Between Creation and Conservation (Researcher: Sophie Lei, Affiliation: Roma III University \& Maastricht University); 14 Ownership, Information, Control, and Access: A Study in Practice and Ethics (Researcher: Zoë Miller;Affiliation: Tate London \& Maastricht University); 15 Private Collections as Care-takers (Researcher: Artemis Rüstau, Affiliation: Maastricht University).

[4] Operational Guidelines for the Implementation of the Word Heritage Convention, World Heritage Committee and World Heritage Centre, UNESCO 2005.
Strategies for Computer-Based Artworks (Researcher: Claudia Röck, Affiliation: University of Amsterdam); 7 Conservation of Contemporary Art and Ethnographic Materials: Relationships, Similarities and Differences (Researcher: Caitlin Spangler-Bickell, Affiliation: Maastricht University \& MUDEC Milan); 8 The Exhibition as a Conservation Tool: Examining Changes in Presentation Discourses and Practices (Researcher: Panda de Haan, Affiliation: University of Porto); 9 Artist Interviews and Artist Participation as Research Tools in Conservation Practices, (Researcher: Aga Wielocha, Affiliation: University of Amsterdam); 10 Audience Participation in Performance-based Art (Researcher: Iona Goldie-Scot, Affiliation: Maastricht University); 11 Database for the Documentation of Contemporary Art (Researcher: Dušan Barok, Affiliation: University of Amsterdam); 12 Contemporary Art Conservators and Curators: Roles, Collaboration, Training and Ethics (Researcher: Maria Theodoraki, Affiliation: Universidade Nova de Lisboa); 13 On the Artists'Side: Bridging the Gap Between Creation and Conservation (Researcher: Sophie Lei, Affiliation: Roma III University \& Maastricht University); 14 Ownership, Information, Control, and Access: A Study in Practice and Ethics (Researcher: Zoë Miller;Affiliation: Tate London \& Maastricht University); 15 Private Collections as Care-takers (Researcher: Artemis Rüstau, Affiliation: Maastricht University).

[4] Operational Guidelines for the Implementation of the Word Heritage Convention, World Heritage Committee and World Heritage Centre, UNESCO 2005.

\section{Referencias /references}

ALTHÖFER, H. (1960). “Einige Probleme der Restaureierung moderner kunst". en Das kunstwerk 5-6 /XIV, nov./dic.

ALTHÖFER, H. (1977). “Fünf Aufgaben zur Erhaltung der modernen kunst”, en Das kunstjahrbuch, 77/78, 149-155.

HUMMELEN, IJ.; SILLEL, D. (1999). "Modern Art: Who Cares? An interdisciplinary research project and an international symposium on the conservation of modern and contemporary art", Foundation for the Conservation of Contemporary Art

HUMMELEN, IJ. (1999). "The Conservation of Contemporary Art: New Methodos and Strategies?" en Corzo, M.A., Mortality immortality: The legacy of 20th century art, Los Angeles, Getty Conservation Institute, 171-175.

HUMMELEN, IJ. (2006). "Conception, creation and re-creation. Embodied Knowledge and the preservation of contemporary art", en Delgado, J., Mimoso, J.M., International Seminar. Theory and Practice in Conservation, Lisbon, National Laboratory of Civil engineering.

DEL FRESNO, R. (2017). La entrevista al artista emergente como modo de conservación preventiva. Estudio aplicado a los proyectos Perspectives Art Inflammation and Me y Perspectives, Art Liver Diseases and Me. Tesis doctoral. Universidad Politécnica de Valencia.

JADZINSKA, M. (2008) Authenticity in Modern Art in the light of the theories of Cesare Brandi. en: Basile, Giuseppe. II pensiero di Cesare Brandi dalla teoria alla pratica. Atti dei seminari di Monaco, Hildesheim, Valeza, Lisbona, Londra, Varsavia, Bruxelles, Parigi. Il prato editore. Padova, 264.

JADZINSKA, M. (2012) "Back to the Future: authenticity and its influence on the conservation of Modern Art", en Szmelter, l., Innovative Approaches to the complex care of Contemporary Art, Archetype Publications, 82-99.

MARKEVICIUS, T. (2019). "Decision-making authenticating modern and contemporary art: challenges articulating temporality, change and authenticity momentum", en: MACCH Conference 2019: Bridging the Gap. Theory and Practice in the Conservation of Contemporary Art, 24 - 27 March 2019. Jan van Eyck Academie, Maastricht, The Netherlands.

NACCA (2019). Bridging the Gap. Theory and Practice in the Conservation of Contemporary Art. http://nacca.eu/conference-2019/

PUGLIESE, M. y FERRIANI, B. (2009). Monumenti effimeri. Storia e conservazione delle installazioni, Electa Mondadori, Milán. 
PUGLIESE, M. (2002). Scolpire lo spazio: tecnica e metodologia della scultura dall'antichita al contemporaneo, Campanotto., Pasian di Prato.

PUGLIESE, M. y FERRIANI, B. RAVA, A. (2008). "Time, originality and materiality in contemporary art conservation, The theory of restoration by Cesare Brandi, between tradition and innovation", en 15th Triennial Meeting. New Delhi, ICOM, 484-488. https://www.icom-cc-publications-online. org/1892/Time-originality-and-materiality-in-contemporary-art-conservation-The-theory-of-restoration-by-Cesare-Brandi-betweentradition-and-innovation

BRACKER, A. (2009). Conservation, principles, dilemmas and uncomfortable truths, London, Victoria and Albert Museum.

RAVA, A, (2013). “Forma e memoria, la conservazione dell arte contemporanea", en Teorie e pratiche del restauro nell arte contemporanea, Skira, Milán, $147-155$.

RAVA, A, (2003). "Fragile contemporaneo, en Rapporto restauro". Il Giornale dell Arte, $219,4$.

SANTABARBARA, C., (2016). “Heinz Althöfer, el inicio de la teoría de la restauración del arte contemporáneo Heinz Althöfer, the beginning of the Theory of Conservation of Contemporary Art". Revista e-rph18, 52-69. http://revistaseug.ugr.es/index.php/erph/article/view/5198

SCHINZEL, H., (2003). "Visibility of restoration, legibility of artwork : the topicality of a compromise". En Visibilité de la restauration, Lisibilité de l'œuure. Actes du 5ème Colloque International de l'Association des Restaurateurs d'Art et d'Archéologie de Formation Universitaire, 13-15 juin 2002. Paris: CRBC-ARAAFU, 55-63

SCHINZEL, H., (2004). "Zeitgenössische Kunst und Restauriertheorie", in Museum Aktuell Dez. 110: 19 - 27.

SZMELTER, I., SCHOLTER, S., (1999) "The conservation of modern art in Eastern Europe" en Modern Art: Who Cares? An interdisciplinary research project and an international symposium on the conservation of modern and contemporary art, The Foundation for the Conservation of Modern Art and the Netherlands Institute for Cultural Heritage, 322-326.

SZMELTER, I., (2012) “An innovative Complex Approach to Visual Art Preservation" en Innovative Approaches to the complex care of Contemporary Art, Â Archetype Publications, London. 10-33.

SCHÄDLER-SAUB, U. (2010) "Conserving modern and contemporary art: reflections on theory and practice in Italy", en Theory and practice in the conservation of modern and contemporary art: reflections on the roots and the perspectives. Archetype publications. https://sisis.rz.htw-berlin.de/ inh2011/12398348.pdf

ICOMOS (1994). Documento de Nara. https://www.iccrom.org/sites/default/files/publications/2020-05/convern8 06 docudenara esp.pdf

SBMK, ICN (2010) "Contemporary art, who cares?", Foundation for the Conservation of contemporary Art y The Netherlands Institute for Cultural Heritage en colaboración con la University of Amsterdam (UvA), Amsterdam.

UNESCO. (2005) Operational Guidelines for the Implementation of the Word Heritage Convention, World Heritage Committee and World Heritage Centre.https://whc.unesco.org/en/guidelines/

TH KÖLN (2019). The Decision-Making Modelfor. Contemporary Art Conservation and Presentation Mai 2019 Cologne Institute of Conservation Sciences.https://www.sbmk.nl/source/documents/f02 cics gsm fp dmmcacp 190513.pdf

\section{Autor/es}

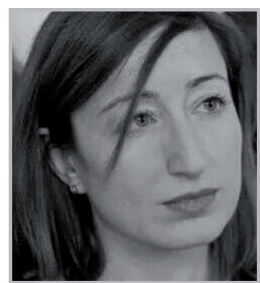

\section{Carlota Santabárbara}

carlotasantabarbara@gmail.com Departamento de Exposiciones del Museo Nacional Reina Sofía de Madrid

\section{http://orcid.org/0000-0003-3767-3826}

Carlota Santabárbara Morera es doctora en Historia del Arte por la Universidad de Zaragoza. Su tesis "Conservación de Arte Contemporáneo, Historia, Teoría y Crítica" (2016) fue calificada de Cum Laude y recibió mención europea gracias a la investigación realizada en el ICCROM durante su estancia en Roma.
Es Licenciada en Historia del Arte por la Universidad de Zaragoza (2001), Diplomada en Conservación y Restauración de Bienes Culturales, con la especialidad en pintura (2004) por la Escola Superior de Conservació i Restauració de Béns Culturals de Catalunya. En este área, obtuvo dos becas en el Centre de Restauració de Béns Mobles de Catalunya (CRBMC) en Valldoreix, Barcelona entre 2006 y 2008, y donde desarrolló trabajos de investigación, conservación y restauración de pintura. También ha realizado un postgrado en Dirección y Gestión de Instituciones Culturales en la Universidad Pompeu Fabra de Barcelona (2008). Acerca de su experiencia profesional, ha trabajado como conservadora, comisaria y coordinadora de exposiciones de arte contemporáneo, así como crítica de arte (2011-2021), y como restauradora de patrimonio, pintura mural, pintura sobre lienzo 
y sobre tabla y escultura (2004-2020). Obtuvo una beca en 2014 en el Museo Nacional Reina Sofía, de conservación de videoarte e instalaciones (FormArte, Ministerio de Cultura de España). En 2008-2009 en el Centro de Arte y Naturaleza (CDAN), realizó una investigación sobre conservación de arte contemporáneo. Ha realizado algunas estancias, como en 2013 en el ICCROM, en Roma, en 2004 en el Museo Thyssen Bornemisza, como restauradora de pintura, en Madrid; y en 2006 en el Instituto Valenciano de Arte Moderno, también como restauradora de arte contemporáneo. Actualmente y desde el año 2020, es investigadora en el Departamento de Exposiciones del Museo Nacional Reina Sofía de Madrid (Spain). También, es co-coordinadora del grupo de trabajo del Arte Contemporáneo y Nuevos Medios (2020-actualidad).

Artículo enviado el 13/11/2021 Artículo aceptado el 01/12/2021

(c) (i) $(9)$

https://doi.org/10.37558/gec.v20i.1079 